Article

\title{
Inter-religious Cooperation for HIV Prevention in Uganda: A Study among Muslim and Christian Youth in Wakiso District
}

\author{
Magid Kagimu ${ }^{1,2,3, *}$, David Guwatudde ${ }^{2}$, Charles Rwabukwali ${ }^{4}$, Sarah Kaye ${ }^{1,5}$, \\ Yusuf Walakira ${ }^{1}$ and Dick Ainomugisha ${ }^{1}$
}

1 Islamic Medical Association of Uganda, P. O. Box 2773, Kampala, Uganda

2 Makerere Univesity School of Public Health, P. O. Box 7062, Kampala, Uganda;

E-Mail: dguwatudde@musph.ac.ug

3 Department of Medicine, Makerere University College of Health Sciences, P. O. Box 7072, Kampala, Uganda

4 Department of Sociology, Makerere University, P. O. Box 7062, Kampala, Uganda; E-Mail: crwabukwali@ss.mak.ac.ug

5 Makerere University School of Public Health - CDC/HIV/AIDS Fellowship Programme, P.O. Box 7072, Kampala, Uganda

* Author to whom correspondence should be addressed; E-Mails: mmkagimu@ utlonline.co.ug or imau@utlonline.co.ug; Tel.: +256-782-016868.

Received: 30 November 2011 / Accepted: 16 December 2011 / Published: 20 December 2011

\begin{abstract}
Inter-religious cooperation has been recommended to address various issues for the common good. Muslims and Christians in Uganda are working together on HIV prevention in this spirit. A study was done to compare HIV prevalence and HIV-risk behaviors between Muslims and Christians. A total of 2,933 Christian and 1,224 Muslim youth between 15-24 years were interviewed and tested for HIV. The HIV prevalence was significantly lower among Muslims (2\%) compared to Christians (4\%). Muslims were more likely to be circumcised, avoid drinking alcohol and avoid having first sex before 18 years. These behaviors which may have led to lower HIV infections among Muslims are derived from Islamic teachings. Muslim religious leaders need to continue to emphasize these teachings. Christian religious leaders may need to consider strengthening similar teachings from their faith tradition to reduce new HIV infections among their communities. Muslims and Christians working together as good neighbors, in the spirit of inter-religious cooperation, can generate evidence-based data that may assist them to improve their HIV prevention interventions. By sharing these data each community is likely to benefit from
\end{abstract}


their cooperation by strengthening within each religious tradition those behaviors and practices that appear helpful in reducing new HIV infections.

Keywords: inter-religious cooperation; Muslims; Christians; youth; HIV prevention; Uganda

\section{Introduction}

This paper has two main purposes: (1) to give the background and then describe interfaith efforts for HIV prevention in Uganda; and (2) to compare Muslim and Christian youth regarding HIV-risk behaviors and HIV prevalence rates.

\subsection{Inter-religious Cooperation in the Holy Bible and Holy Qur'an}

Inter-religious cooperation has been recommended to address various issues for the common good including the HIV/AIDS pandemic [1]. The basis for this is found in the scriptures of the different religious traditions. In case of Christians, one teaching in the Holy Bible on this issue is as follows:

When the Pharisees heard that Jesus had silenced the Sadducees, they came together and one of them a teacher of the Law, tried to trap him with a question. "Teacher" he asked, "which is the greatest commandment in the Law"? Jesus answered, "Love the Lord your God with all your heart, with all your soul and with all your mind". This is the greatest and the most important commandment. The second most important commandment is like it: "Love your neighbor as you love yourself. The whole law of Moses and the teachings of the prophets depend on these two commandments". (Holy Bible: Matthew 22:34-40. Quoted from the Good News Bible published by The United Bible Societies).

It is important to note that in this faith teaching the neighbor is not classified as belonging to any particular religion. This is supportive of inter-religious cooperation. For the Islamic faith similar teachings from the Holy Qur'an are as follows:

Say: We believe in Allah and the revelation given to us and to Abraham, Ismail, Isaac, Jacob and the Tribes and that given to Moses and Jesus and that given to all prophets from their Lord. We make no difference between one and another of them and we bow to Allah in Islam (Holy Qur'an 2:136. Translated by Abdullah Yusuf Ali).

This teaching supports inter-religious cooperation within the Abrahamic religions. A similar supportive teaching is as follows:

Those who believe in the Qur'an, and those who follow Jewish scriptures and the Christians and the Sabians and who believe in Allah and the Last Day, and work righteousness, shall have their reward with their Lord: on them shall be no fear nor shall they grieve”. (Holy Qur'an 2:62. Translated by Abdullah Yusuf Ali). 


\subsection{Theories upon which Inter-religious Cooperation may be Anchored}

Inter-religious cooperation increases social capital that can be used to reduce HIV transmission in accordance with the social capital theory proposed by Bourdieu, Coleman and Putman. Social capital is defined as features of social organizations such as networks, norms and trust that facilitate coordination and cooperation for mutual benefit. It can further be subdivided into bonding, linking and bridging capital. Bonding social capital refers to relations formed by social networks between homogeneous groups. Linking social capital provides links between social classes and provides vertical ties. Bridging social capital provides bridges between individuals and groups from different societies which enable members to access a wider range of resources, ideas and information. Social capital influences individual behavior which may subsequently result in reduced HIV transmission. For example, strong social networks may result in social and cultural pressures that discourage high risk sexual behaviors. Such networks including those developed through inter-religious cooperation, may also provide avenues for exchange of information that may be used to shape community norms for healthy behavior. Religious organizations usually focus on developing social relations and they are highly trusted in the community. People's participation in these social groups (structural social capital) and the rules, values, norms, trust and solidarity developed (cognitive social capital) may influence HIV transmission through changing risky behavior. As a result of inter-religious cooperation, social capital increases and so does its potential impact on HIV transmission. Through inter-religious cooperation information may be gathered on behaviors and practices likely to reduce new HIV infections. This increases the cognitive social capital of those involved. The information may be used by the cooperating religious organizations to encourage their respective congregations to adopt identified low HIV-risk behaviors and practices individually and within their families. The adoption of such behaviors is more likely to be successful if the messages are delivered by trusted religious organizations working together and supporting each other for the benefit of their communities. By working together their social capital increases and their impact in promoting low HIV-risk behaviors and practices is more likely to be enhanced thereby reducing new HIV infections [2].

According to some scholars spiritual capital is a subset of social capital and religious capital is a subset of spiritual capital [3]. Religious capital is defined as the degree of mastery of and attachment to a particular religious culture. The mastery refers to knowledge and familiarity needed to appreciate a religion. The attachment refers to emotional attachments and experiences that become intrinsic to someone who fully appreciates the religion [4]. Religions that foster bridging religious capital which turns members outwards and encourage concern for others are favored by some scholars because they are more likely to promote inter-religious cooperation. Other religions may foster predominantly bonding religious capital which turns people inward and focuses concern on friends and fellow members. The tendency for some scholars is therefore to favor inclusive over exclusive religious denominations since they possess additional bridging capital [3].

Social capital is not always positive and more is not necessarily better especially if it leads to exclusion between groups. Networks of social capital including religious organizations may operate in a hierarchical manner, limiting participation and initiative of their members, resulting in restricting the potential of the social capital gained. For religious communities to effectively work for social transformation, they must themselves be transformed from structures that reinforce exclusion to those 
that promote inclusion. For example if religious organizations with high social capital limit the initiative of their members and discourage them from adopting low HIV-risk behaviors, this is likely to result in continued HIV transmission. There are five conditions that optimize the usefulness of social capital. These are: (1) informal networks, that work together on particular issues as need arises; (2) stock of social trust such as that enjoyed by religious institutions; (3) networks at multiple levels that foster bonding, linking and bridging social capital; (4) mediating actors who may be individuals or organizations with the expertise to help others take advantage of opportunities that exist in their environment; and (5) constructive interaction between the networks and institutions. These five conditions that maximize the social capital of religious communities can largely be met through interfaith solidarity. This has been defined as multi-religious and religious-secular cooperation unified around common goals such as HIV prevention and control [5].

There are advantages in inter-religious cooperation compared to inter-religious competition, when planning and implementing HIV prevention interventions. Cooperative people on issues for the common good, such as HIV prevention, compared to competitive people, have the following advantages: (1) they have a sense of connectedness to others; (2) they are trusting and open; (3) they share ideas, art and culture; (4) they are hospitable and generous; (5) they have nothing to hide and their honesty and integrity comes naturally; (6) they experience joy both in personal success and in the achievement of others; (7) they promote love of their neighbors; (8) they have a sense of responsibility for each other, each striving whenever possible to benefit the other; (9) they promote peace between each other and between nations; and (10) they do not focus on having things but focus on being useful to others [6]. All these advantages may be cultivated and harvested in the processes of inter-religious cooperation for HIV prevention. With this spirit, people are more likely to support each other in reducing HIV-risk behaviors so that the common goal of HIV prevention and control is achieved. In a competitive environment people may have predominantly, bonding social capital which focuses only on their members. Such people may not benefit from the lessons learnt about HIV-risk behaviors from their neighbors. New HIV infections, which could have been prevented, may therefore continue to occur and this may eventually affect everyone in the neighborhood.

\subsection{Mediating Actors in Inter-religious Cooperation: The Example of the Islamic Medical Association of Uganda (IMAU)}

The Islamic Medical Association of Uganda is a faith-based non-governmental organization that has been using the principles of inter-religious cooperation to address HIV/AIDS issues, by performing the role of a mediating actor and catalyst for the target communities. The IMAU started with a project within Muslim communities entitled "Family AIDS Education and Prevention Through Imams" (FAEPTI), in 1992. It covered the districts of Mpigi in central Uganda and Iganga in the east of the country. In this project, Imams and their assistants were trained to regularly educate their communities regarding HIV prevention using a curriculum with scientific information supported by Islamic faith teachings [7]. This project was evaluated after 2 years and found to have resulted in a significant increase in correct knowledge about HIV prevention. There was also a significant reduction in selfreported sexual partners among young respondents. It was concluded that collaboration between health professionals and religious leaders can be achieved and it can contribute to the success of HIV 
prevention efforts [8]. One of the issues raised by the Imams, was that during project implementation, their neighbors, the Christians, also wanted to benefit from HIV/AIDS education. The FAEPTI project initially worked only with Muslims because IMAU had the comparative advantage of being familiar with the Islamic culture. There were other faith-based organizations such as the Church Human Services AIDS Prevention Programme (CHUSA), which worked among the Protestant communities and the Uganda Catholic Secretariat which worked with the Catholic communities. Each religious denomination worked predominantly with their own congregations. This was part of the multi-sectoral approach strategy adopted by the Uganda government to ensure all Ugandans participate in combating HIV/AIDS in the sectors where they had a comparative advantage [9]. Catholics, Protestants and Muslims did not have any formal organization that fostered inter-religious cooperation. This was partly because there were historical tensions between these communities related to the struggle for political power and converts within Uganda [10]. However, there was informal inter-religious cooperation among neighboring churches and mosques. This often took place spontaneously especially when there was a crisis in the community such as a death. Informal inter-religious cooperation for a lifethreatening condition such as HIV/AIDS was therefore easily accepted.

In 1995, a pilot project where both Muslims and Christian religious leaders were trained together on issues of AIDS prevention and control was started by IMAU in Kampala district. It was entitled "Community Action for AIDS Prevention" (CAAP). The curriculum used included scientific information supported with both Muslim and Christian faith teachings. After the training, the religious leaders and their communities started regularly educating their respective communities. The project was successful and the religious leaders appreciated learning and working together to address the issues of HIV/AIDS. The experience was enriching to both communities [11]. They overcame the initial tensions and suspicions that occur at the beginning of forming new relationships. It has been noted that the societal strains among Muslims and Christians may result in a mindset of "We against them" which has to be overcome for the purpose of inter-religious cooperation [12]. Some church and mosque leaders had to consult their leaders about the informal inter-religious cooperation. They all got the approval from their superiors because the issue being addressed was a threat to all and addressing it was a priority for the common good. Formal inter-religious cooperation between Muslims and Christians occurred later in 2001 with the formation of the Inter-religious Council of Uganda (IRCU).

In 2002, another pilot project was started by IMAU in the capital city district of Kampala, to mobilize both Muslim and Christian communities to address the new issues that had emerged of prevention of Mother to Child HIV transmission (PMTCT) and antiretroviral therapy (ART). The training methodology was similar to the CAAP project approach and a curriculum with scientific information and supportive religious teachings was used. The project was named "Community Mobilization Model for Prevention of Mother to Child HIV Transmission". The project was successful and both Muslim and Christian communities welcomed the opportunity to learn and work together on the new HIV/AIDS issues. It was concluded that faith-based organizations (FBOs) had a great potential to deliver PMTCT and ART related services through their health facilities and religious establishments. This potential needed to be utilized by forming partnerships with FBOs and building their capacities to deliver these services [13].

In 2004, the project was expanded to cover both Kampala and Wakiso districts and named "Community Action to Protect Children from AIDS" (CAPCA). Wakiso district surrounds 
Kampala district and it was formerly part of Mpigi district. In 2005, IMAU opened a hospital in Wakiso district called "Saidina Abubakar Islamic Hospital" (SAIH). The hospital is located 14 km north of Kampala city on Bombo road. The hospital started offering general medical services as well as HIV/AIDS services including PMTCT and ART to the surrounding communities. This was through a project named "Community Action for Prevention, Treatment and Care of AIDS" (CAPTCA). In this project, hospital staff trained trainers, who in turn trained both Muslim and Christian religious leaders and their assistants, on issues of HIV/AIDS prevention and control including PMTCT, ART and how to refer clients to health facilities for HIV/AIDS services. The hospital staff and IMAU trainers provided regular support supervision to the religious leaders and their assistants who were called community educators. These community educators educated their communities through sermons, group talks and home visits. One of the indicators of success of the CAPCA project was referral of pregnant mothers for PMTCT. It was planned that within one year, 450 community educators would refer 4500 pregnant mothers to health facilities that provide PMTCT services. Between April 2009 and March 2010 the community educators referred 3,097 pregnant mothers, which was approximately $70 \%$ of the target. The referrals were objectively verified by counting the referral cards brought by the pregnant mothers from the community educators to service providers at the health facilities.

In 2010 another project offering predominantly home-based HIV counseling and testing was started by IMAU using a similar approach to the previous projects. It was named "Community Action for Promotion of HIV Counseling and Testing” (CAPCOT). In training the religious leaders in all these projects the training curricula were similar, containing both scientific information and supportive religious teachings from both Muslim and Christian faiths. The emphasis varied depending on the service being primarily targeted [14]. The training workshops varied between 3-5 days and participants included both Muslims and Christians. They all appreciated learning together and working together. They said that this approach enriched their understanding of each other's faith teachings as well as their own.

After the training each religious denomination went ahead to educate members of their respective congregations. They taught the same scientific information but focused only on supportive faith teachings relevant to their respective religious denomination. Both Muslims and Christians promoted abstaining from sex for the unmarried and being faithful in marriage because they were in line with their faith teachings. Condom use was not greatly promoted. It was left to the respective religious communities to handle according to their religious guidance. For example the Catholic church did not advocate for condoms, yet agreed not to spend its energy opposing them [9]. The Protestants and Muslims accepted condom use among discordant married couples. Some Muslim scholars argued that condoms could even be used outside marriage within the general law of choosing the lesser of 2 evils. Sex outside marriage is a major evil but exposing another person to a deadly disease even though that person may be a companion in the evil is a much greater evil. If Muslims find themselves in a situation where they have to choose between two evils, they are encouraged to choose the lesser evil. Sex outside marriage with a protective condom is a lesser evil compared to having this type of sex without a condom [15]. 


\subsection{Justification for the Study and Study Objectives}

Despite the positive qualitative observations on the value of their inter-religious cooperation, there was limited empirical quantitative data on HIV prevalence and HIV-risk behaviors, comparing Muslim and Christian faith traditions, which could be used to enrich their combined efforts to prevent new HIV infections in their communities. The recognized high-risk behaviors driving the HIV epidemic in Uganda include sexual activity especially with multiple sexual partners, lack of condom use, lack of male circumcision, and alcohol and narcotic drug use [16]. The first objective of the study was to provide current data that compares HIV prevalence and HIV-risk behaviors among Muslims and Christians for the purpose of informing, improving and enriching their combined efforts to reduce new HIV infections among their communities. The HIV-risk behaviors selected for the study were those known to be driving the HIV epidemic.

It is recommended by Uganda AIDS Commission that surveys with both serological and behavioral components should be institutionalized and conducted regularly at least every 2-3 years to improve data availability for evidence-based planning and decision making [16]. The second objective of the study was to make a contribution to this recommendation by providing baseline HIV serological and behavioral data from a large sample of Muslim and Christian youth 15-24 years, living in Wakiso district, near Saidina Abubakar Islamic Hospital, which could be used in future surveys to track trends in these markers within the two religious communities. It was noted in several studies in Uganda that the HIV prevalence and incidence were lower among Muslims compared to non-Muslims. Researchers in Masaka district in Uganda reported in 1994, that there was a five-fold increased risk of HIV infections for non-Muslims compared to Muslims. In this case-control study there were only 23 Muslim men who were all circumcised and only three (3.3\%) non-Muslims had been circumcised. The researchers suggested that male circumcision could have a protective effect. However, they could not rule out the compounding factor of the Islamic religion which could result in differences in lifestyle among Muslims and Christians. They recommended more studies to provide more data on this issue [17].

In the last Ugandan census which was done in 2002, the population of Uganda was 24.4 million. The population distribution by religious denomination was as follows: Catholics $41.9 \%$, Church of Uganda (Protestants) 35.9\%, Muslims 12.1\%, Pentecostals 4.6\%, Seventh Day Adventists 1.5\%, other Christians $1.2 \%$, Orthodox $0.1 \%$, Traditional $1.0 \%$, Bahai $0.1 \%$, other non-Christians $0.7 \%$ and None (no religion) $0.9 \%$. The majority of the people in Uganda were therefore, Christians and Muslims forming $85.2 \%$ and $12.1 \%$ of the population respectively. These religious denominations were the ones included in our study because inter-religious and inter-faith cooperation in Uganda predominantly involves these two religious communities. The population growth between 1991 and 2002 was reported to be $3.3 \%$. If this growth remained the same, the population in 2010 was approximately 31 million. This is close to the projected 2010 mid-year Ugandan population by the Uganda Bureau of Statistics, which was 31.8 million. [18]. In the 2004-05 Uganda HIV/AIDS sero-behavioral survey in which 18,525 respondents across Uganda between 15-59 years were studied, the HIV prevalence by religious denomination was as follows: Catholics 6.3\%, Protestants 7.1\%, other Christians 6.3\%, others $5.5 \%$ and Muslims 5.0\%. The overall HIV prevalence in the country in the 15-49 year age group was $6.4 \%$. The HIV prevalence in the 15-49 year age group in the central region where Wakiso 
district and Saidina Abubakar Islamic Hospital are located was 8.5\%. The HIV prevalence among the youth in the 15-24 year age-group in the central region was 3.4\% [19]. From this national HIV serosurvey, Uganda had a significant HIV/AIDS burden. It was estimated that every day in 2005 approximately 370 individuals became HIV infected, 290 became ill enough to require antiretroviral therapy and 210 died of AIDS. HIV/AIDS caused every third adult death and a fifth of all deaths making it the leading cause of mortality. At least 647,000 (80\%) HIV infected adults were unaware of their infection. Researchers recommended that intensified HIV prevention efforts were needed to halt or reverse the expansion of Uganda's HIV epidemic. Prevention of adult HIV transmission remains key in minimizing the burden of HIV in Uganda [20].

The observation that Muslims have the lowest HIV prevalence among the religious denominations is likely to provide useful strategic information that may guide Uganda's HIV prevention efforts, if it is further studied in more detail. The national HIV sero-behavioral survey did not provide data to explain this observation. The third objective of our study was to provide empirical quantitative data on the possible explanations of the lower HIV prevalence among Muslims compared to Christians, which could be used to strengthen HIV prevention efforts. This information could also be used to highlight the potential role of religiosity in HIV prevention. Religious organizations are recognized for playing an important role in preventing new HIV infections in Uganda. However, there is limited empirical data to improve understanding of what faith communities can contribute in addressing HIV prevention and control. Getting this data is critical for all stakeholders interested in promoting religiosity for HIV prevention, treatment and care [21]. One study in Uganda showed that a high level of religiosity was associated with a low level of premarital sexual permissiveness [22]. More data is needed to understand various aspects of religiosity and its role in combating the HIV/AIDS epidemic among Ugandan communities. The fourth objective of the study was to provide data that could be shared by Muslims and Christians in identifying behaviors that were likely to reduce new HIV infections so that both communities target promoting these behaviors using supportive faith teachings in each religious tradition.

\section{Methods}

\subsection{Study Setting}

The study was done among communities surrounding Saidina Abubakar Islamic Hospital in Wakiso district. This district is in central Uganda along the shores of Lake Victoria.

\subsection{Study Participants}

A convenience sample of 30 mosques and 30 churches surrounding the hospital was selected to participate in the study. These places of worship were chosen because they were near the hospital and were actively involved in the CAPTCA project. The IMAU did not have sufficient resources to sample places that were far away from the hospital. At each place of worship between 40-100 respondents were recruited. Some of the respondents were likely to have been exposed to faith-based education by the community educators. However, this was not assessed because it was not included in the objectives of the study. The community educators guided research assistants into homes with clients 15-24 years 
old. This age group was selected because they are more likely to have new HIV infections. The HIV prevalence in this group is a proxy indicator of HIV incidence [23]. The behaviors in this age-group are therefore, likely to influence new HIV infections.

\subsection{Measurements}

\subsubsection{HIV Testing}

HIV counseling and testing was done by hospital nurses, and laboratory staff. Rapid test kits were used in accordance with the Uganda Ministry of Health guidelines [24]. The blood was first tested using Determine HIV-1/2 (Abbot, Tokyo, Japan) rapid test kit. For an HIV negative test result no further test was done. For an HIV positive result another test was done using the HIV-1/2 STAT-PAK (Chembio, Medford, NY) test kit. If the result was again positive the respondent was recorded as positive. If the result was negative, a third test was done as a tie breaker using Uni-Gold Recombigen HIV test (Trinity Biotech, Wicklow, Ireland). If this gave a positive result the respondent was recorded as HIV positive and if it was negative the respondent was recorded as HIV negative.

\subsubsection{Behaviors}

A questionnaire was administered to the respondents to collect data on socio-demographic factors as well as HIV-risk behaviors. The behaviors selected were those likely to be driving the epidemic [16]. The responses to questions were intended to identify those with high HIV-risk behaviors and those with low HIV-risk behaviors for the purpose of comparison in quantitative data analysis. The hospital staff were trained to interview the respondents before performing HIV testing. The interview technique was used because the literacy level in these communities was relatively low.

\subsection{Statistical Analysis}

Double data entry was done in EpiData version 2.1b. Statistical analysis was done in STATA version 10.0 computer program. The information was organized into categorical frequency data and the chi-squared test used to assess the difference between groups. The crude odds ratio was used to determine the magnitude of the association between the factors being studied. A p-value of less than 0.05 was considered significant.

\subsection{Ethical Considerations}

The study was approved by Makerere University School of Public Health Institutional Review Board as well as Uganda National Council of Science and Technology. All respondents were informed about their HIV status. The HIV negative respondents were counseled about HIV prevention measures. The HIV positive respondents were also counseled and referred to SAIH for follow up and assessment for antiretroviral therapy. 


\section{Results (Table 1 and Table 2)}

\subsection{Male Circumcision}

Between July and December 2010 a total of 2933 Christian and 1224 Muslim youth between 15-24 years were interviewed and tested for HIV. It was initially planned to have an equal number of Muslims and Christians for comparison purposes. However, within the study period fewer Muslims in the target age-group were obtained due to their lower proportion in the study area. IMAU did not have resources to recruit more Muslims beyond the planned study period. From the study findings, Muslims were significantly more likely to be circumcised compared to Christians. Circumcision was more likely to be done in infancy among the Muslims compared to the Christians.

\subsection{Drinking Alcohol}

Christians were more likely to have ever drank alcohol, ever been drunk, and ever taken alcohol before sex compared to Muslims. Christians were also more likely to report drinking nowadays.

\subsection{Age of First Sex}

Christians were more likely to have had their first sex at an age less than 18 years compared to the Muslims.

\subsection{Other HIV-Risk Behaviors}

There was no significant difference between Muslims and Christians regarding abstaining from sex, being faithful in marriage and condom use. There was also no significant difference between them regarding the number of sexual partners. In addition, there was no difference between the Muslims and Christians regarding ever using narcotics for recreation.

\subsection{Association between HIV-Risk Behaviors and HIV Infections (Table 1)}

HIV infections were significantly higher among respondents who were not circumcised, did not abstain from sex, had multiple sexual partners outside marriage, had multiple lifetime sexual partners and had multiple lifetime marital sexual partners acquired through a religious, government or cultural contract. HIV infections were also significantly higher among respondents who had ever drank alcohol, ever been drunk, were drinking nowadays, ever taken alcohol before sex and had ever used narcotics for recreation.

\subsection{Comparison of HIV Prevalence between Christians and Muslims}

The HIV prevalence was significantly higher among Christians (4\%) compared to Muslims (2\%); (odds ratio $1.53,95 \% \mathrm{CI} 1.01-2.32, \mathrm{p}=0.043$ ). 
Table 1. Association between HIV-risk behaviors and HIV infections among Muslims and Christians combined.

\begin{tabular}{|c|c|c|c|c|c|}
\hline Behavior or practice & $\begin{array}{l}\text { HIV positive } \\
\text { n }(\%)\end{array}$ & $\begin{array}{l}\text { HIV negative } \\
\text { n }(\%)\end{array}$ & Odds ratio & $95 \% \mathrm{CI}$ & p-value \\
\hline \multicolumn{6}{|l|}{ Male circumcision } \\
\hline Yes & $13(2)$ & $749(98)$ & & & \\
\hline No & $42(4)$ & $1,094(96)$ & 2.21 & $1.17-4.14$ & 0.012 \\
\hline \multicolumn{6}{|c|}{ Age of male circumcision } \\
\hline Infancy & $13(2)$ & $670(98)$ & & & \\
\hline Other age & $2(2)$ & $126(98)$ & 0.82 & $0.18-3.67$ & 0.793 \\
\hline \multicolumn{6}{|l|}{ Ever had sex } \\
\hline No (Abstaining) & $12(1)$ & $1,071(99)$ & & & \\
\hline Yes & $123(4)$ & $2,929(96)$ & 3.75 & $2.06-6.82$ & $<0.001$ \\
\hline \multicolumn{6}{|l|}{ Age of first sex } \\
\hline$\geq 18$ years & $100(4)$ & $2,271(96)$ & & & \\
\hline$<18$ years & $20(3)$ & $593(97)$ & 0.77 & $0.47-1.25$ & 0.283 \\
\hline \multicolumn{6}{|l|}{ Sex outside marriage } \\
\hline No (Being Faithful) & $24(3)$ & $761(97)$ & & & \\
\hline Yes & $33(5)$ & $660(95)$ & 1.59 & $0.93-2.71$ & 0.090 \\
\hline \multicolumn{6}{|l|}{ Ever used a condom } \\
\hline Yes & $90(4)$ & $2,227(96)$ & & & \\
\hline No & $31(4)$ & $663(96)$ & 1.16 & $0.76-1.76$ & 0.493 \\
\hline \multicolumn{6}{|c|}{$\begin{array}{l}\text { Condom use in last sex outside } \\
\text { marriage }\end{array}$} \\
\hline Yes & $18(4)$ & $411(96)$ & & & \\
\hline No & $20(7)$ & $251(93)$ & 1.82 & $0.94-3.52$ & 0.070 \\
\hline \multicolumn{6}{|c|}{$\begin{array}{l}\text { Sexual partners outside } \\
\text { marriage }\end{array}$} \\
\hline One & $9(3)$ & $294(97)$ & & & \\
\hline Multiple & $27(7)$ & $358(93)$ & 2.46 & $1.14-5.34$ & 0.018 \\
\hline \multicolumn{6}{|c|}{ Lifetime sexual partners } \\
\hline One & $8(1)$ & $545(99)$ & & & \\
\hline Multiple & $112(5)$ & $2,275(95)$ & 3.35 & $1.62-6.92$ & $<0.001$ \\
\hline \multicolumn{6}{|c|}{ Lifetime marital sexual partners } \\
\hline One & $22(4)$ & $555(96)$ & & & \\
\hline Multiple & $12(8)$ & $133(92)$ & 2.28 & $1.10-4.73$ & 0.023 \\
\hline \multicolumn{6}{|l|}{ Ever drank alcohol } \\
\hline No & $50(2)$ & $2,350(98)$ & & & \\
\hline Yes & $85(5)$ & $1,639(95)$ & 2.44 & $1.71-3.48$ & $<0.001$ \\
\hline \multicolumn{6}{|l|}{ Ever been drunk } \\
\hline No & $18(3)$ & $535(97)$ & & & \\
\hline Yes & $66(6)$ & $1,099(94)$ & 1.78 & $1.05-3.04$ & 0.031 \\
\hline \multicolumn{6}{|l|}{ Drink nowadays } \\
\hline No & $35(4)$ & $875(96)$ & & & \\
\hline Yes & $49(6)$ & $761(94)$ & 1.61 & $1.03-251$ & 0.034 \\
\hline
\end{tabular}


Table 1. Cont.

\begin{tabular}{|c|c|c|c|c|c|}
\hline \multicolumn{6}{|c|}{ Ever taken alcohol before sex } \\
\hline No & $28(3)$ & $859(97)$ & & & \\
\hline Yes & $49(8)$ & $543(92)$ & 2.77 & $1.71-4.47$ & $<0.001$ \\
\hline \multicolumn{6}{|c|}{$\begin{array}{l}\text { Ever used narcotics for } \\
\text { recreation }\end{array}$} \\
\hline No & $118(3)$ & $3,776(97)$ & & & \\
\hline Yes & $14(7)$ & $185(93)$ & 2.42 & $1.36-4.30$ & 0.002 \\
\hline
\end{tabular}

Table 2. Comparison of HIV status and HIV-risk behaviors and practices among Muslims and Christians.

\begin{tabular}{|c|c|c|c|c|c|}
\hline Characteristic & $\begin{array}{l}\text { Christians } \\
\text { n (\%) }\end{array}$ & $\begin{array}{l}\text { Muslims } \\
\text { n (\%) }\end{array}$ & Odds ratio & $95 \% \mathrm{CI}$ & p-value \\
\hline \multicolumn{6}{|l|}{ HIV status } \\
\hline HIV positive & $106(4)$ & $29(2)$ & & & \\
\hline HIV negative & $2,827(96)$ & $1,185(98)$ & 1.53 & $1.01-2.32$ & 0.043 \\
\hline \multicolumn{6}{|l|}{ Male circumcision } \\
\hline Yes & $196(15)$ & $569(98)$ & & & \\
\hline No & $1,130(85)$ & $12(2)$ & 273.37 & $106.03-704.81$ & $<0.001$ \\
\hline \multicolumn{6}{|c|}{ Age of male circumcision } \\
\hline Infancy & $81(39)$ & $557(92)$ & & & \\
\hline Other age & $129(61)$ & $47(8)$ & 7.44 & $4.78-11.54$ & $<0.001$ \\
\hline \multicolumn{6}{|l|}{ Ever had sex } \\
\hline Yes & $2,188(75)$ & $875(72)$ & & & \\
\hline No (Abstaining) & $745(25)$ & $342(28)$ & 0.87 & $0.75-1.01$ & 0.072 \\
\hline \multicolumn{6}{|l|}{ Age of first sex } \\
\hline$\geq 18$ years & $1,679(78)$ & $699(82)$ & & & \\
\hline$<18$ years & $460(22)$ & $155(18)$ & 1.24 & $1.01-1.51$ & 0.040 \\
\hline \multicolumn{6}{|l|}{ Sex outside marriage } \\
\hline Yes & $488(46)$ & $208(48)$ & & & \\
\hline No (Being faithful) & $566(54)$ & $223(52)$ & 1.08 & $0.86-1.35$ & 0.492 \\
\hline \multicolumn{6}{|l|}{ Ever used a condom } \\
\hline Yes & $1,657(77)$ & $668(77)$ & & & \\
\hline No & $503(23)$ & $194(23)$ & 0.96 & $0.79-1.16$ & 0.645 \\
\hline \multicolumn{6}{|c|}{$\begin{array}{l}\text { Condom use in last sex outside } \\
\text { marriage }\end{array}$} \\
\hline Yes & $294(60)$ & $137(65)$ & & & \\
\hline No & $197(40)$ & $75(35)$ & 0.82 & $0.58-1.14$ & 0.236 \\
\hline \multicolumn{6}{|c|}{$\begin{array}{l}\text { Sexual partners outside } \\
\text { marriage }\end{array}$} \\
\hline One & $209(43)$ & $94(45)$ & & & \\
\hline Multiple & $273(57)$ & $115(55)$ & 0.94 & $0.68-1.30$ & 0.695 \\
\hline \multicolumn{6}{|c|}{ Lifetime sexual partners } \\
\hline One & $400(19)$ & $156(19)$ & & & \\
\hline Multiple & $1,721(81)$ & $672(81)$ & 1.00 & $0.82-1.23$ & 0.991 \\
\hline
\end{tabular}


Table 2. Cont.

\begin{tabular}{|c|c|c|c|c|c|}
\hline \multicolumn{6}{|c|}{ Lifetime marital sexual partners } \\
\hline One & $388(80)$ & 191(80) & & & \\
\hline Multiple & $98(20)$ & $48(20)$ & 0.99 & $0.68-1.46$ & 0.980 \\
\hline \multicolumn{6}{|c|}{ Ever drank alcohol } \\
\hline Yes & $1,526(52)$ & $203(17)$ & & & \\
\hline No & $1,406(48)$ & $1,001(83)$ & 5.35 & $4.48-6.39$ & $<0.001$ \\
\hline \multicolumn{6}{|c|}{ Ever been drunk } \\
\hline Yes & $1,057(69)$ & $111(56)$ & & & \\
\hline No & $466(31)$ & $89(44)$ & 1.82 & $1.35-2.46$ & $<0.001$ \\
\hline \multicolumn{6}{|c|}{ Drink nowadays } \\
\hline Yes & $758(50)$ & $55(27)$ & & & \\
\hline No & $765(50)$ & $147(73)$ & 2.65 & $1.91-3.68$ & $<0.001$ \\
\hline \multicolumn{6}{|c|}{ Ever taken alcohol before sex } \\
\hline Yes & $541(41)$ & $52(30)$ & & & \\
\hline No & $768(59)$ & $123(70)$ & 1.67 & $1.18-2.35$ & 0.003 \\
\hline \multicolumn{6}{|c|}{$\begin{array}{l}\text { Ever used narcotics for } \\
\text { recreation }\end{array}$} \\
\hline Yes & $150(5)$ & $50(4)$ & & & \\
\hline No & $2,754(95)$ & $1,151(96)$ & 0.80 & $0.57-1.10$ & 0.175 \\
\hline
\end{tabular}

\section{Discussion}

Our study was done with inter-religious cooperation between Muslims and Christians in the target communities. It has produced data that may be used by both Muslims and Christians to strengthen their respective as well as their joint HIV prevention efforts. It has identified behaviors that are likely to be driving the epidemic in their communities which Muslims and Christians need to address, both independently and jointly using the strength of their respective religious teachings. These behaviors include not Abstaining from sex, not Being faithful in marriage especially having multiple sexual partners outside marriage, having multiple lifetime sexual partners, drinking alcohol, males not being circumcised and using narcotics for recreation. The study has also identified possible HIV-risk behaviors and practices that may explain the difference in HIV prevalence between Muslims and Christians. These include lower rate of male circumcision, lower rate of male circumcision in infancy, earlier age of first sex, and higher rate of drinking alcohol among Christians compared to Muslims. Both religious communities may use this data in the spirit of inter-religious cooperation to strengthen HIV prevention in their respective communities as well as support each other in these efforts.

One limitation of our study was that a convenience sample was used in selecting both the churches and mosques as well as the individuals interviewed. This could introduce a bias where the most active youth in the church or mosque could have been selected to participate in the study. This may result in underestimating the baseline levels of HIV-risk behaviors and HIV prevalence. Another limitation of the study was that the behaviors were self-reported. Some respondents could have given socially desirable answers to the questions. This could also result in underestimation of the baseline HIV-risk behaviors. However, the effect of these limitations was likely to have been minimal because the findings were consistent with what others had found. For instance, the findings that the HIV 
prevalence was lower among Muslims compared to Christians and that Muslims were more likely to be circumcised, were consistent with what other researchers in Uganda have observed. Researchers in Masaka district in Uganda reported in 1994 that the HIV prevalence was lower among Muslims compared to non-Muslims. In a study of 3,808 respondents, 13-65 years, the HIV prevalence rates by religion were as follows: Catholics $8.7 \%$, Protestant 9.9\%, other religions $8.8 \%$ and Muslims $6.1 \%$ [25]. In another study in the same community researchers reported in 1999 that the HIV incidence rates were significantly lower in Muslims compared to non-Muslims [26]. Researchers in another district called Rakai also reported a lower incidence of HIV infections among Muslims compared to non-Muslims [27]. In the 2004-05 Uganda HIV/AIDS sero-behavioral survey, the HIV prevalence was also lower among Muslims compared to non-Muslims [19].

Our study therefore, adds recent data to that which showed that Muslims had lower HIV prevalence compared to non-Muslims. The possible explanation for the difference that has been given by some scholars, is that Islamic religious teachings restrain Muslims from engaging in behaviors likely to increase transmission of HIV infection. These teachings include prohibition of sex outside marriage and prohibition of alcohol consumption. Islamic teachings also encourage Muslims to circumcise male children in infancy [28]. The empirical data from our study support male circumcision and prohibition of alcohol use as possible explanations for the lower HIV prevalence among Muslims. However, there was no significant difference between Christians and Muslims regarding sex outside marriage. There was no significant difference regarding the rates of Abstaining from sex, Being faithful in marriage and Condom use between Muslims compared to Christians. The ABC strategy which includes Abstinence, Being faithful and Condom use is one of the strategies being promoted to accelerate prevention of sexual transmission of HIV infection in Uganda [29]. Since there was no difference between Muslims and Christians on behaviors related to this strategy in our study, it is likely that both communities were addressing this issue in a similar way.

It was noted that Muslims were less likely to have first sex at a young age less than 18 years. A similar observation was made in West Africa where it was found that the age of first sex was much lower in non-Muslim capitals compared to Senegal's capital Dakar which is predominantly Muslim [30]. This behavior may be protective against HIV infection. It may be the result of Islamic teachings that discourage adultery and fornication. Islamic teachings recommend a deterrent punishment of flogging for those who engage in fornication. However, this is almost next to impossible to prove in an Islamic law (Shari'a) court. The accused will not be punished unless he or she is seen performing actual penetrative sexual intercourse by four persons [15]. From our study, it appears therefore, that the main behaviors that are likely to lower HIV infections among Muslims compared to Christians include male circumcision and avoiding alcohol. There are Islamic teachings that promote these behaviors and emphasize their religious value. The Muslim leaders and other stakeholders should therefore, continue to encourage their communities to follow these teachings more strictly for the benefits of their religious value and that of HIV prevention.

The Christian faith has similar teachings. However, the way they are emphasized and the religious value attached to them differs from that of Muslims. For instance, male circumcision is taught as a religious obligation that must be performed by all Muslims, but this is not so for Christians. Alcohol drinking, even in small amounts is forbidden in Islam but this is not the case in some Christian denominations where small amounts of alcohol may be drank in some religious rituals such as 
celebration of the Holy Communion. These different approaches to issues are in line with the social construction theory. According to this theory there are social processes that lead to variation in religious meanings. Religious beliefs and practices may vary in time and place even if there is an unchanging core. This is why different religious denominations within Christianity and within Islam interpret and practice similar religious teachings differently. This is the origin of various sects within religions which appear to have generally similar core teachings. According to this theory it is possible for religions to adjust the interpretation of their religious teachings depending on the social circumstances of the time. Even religious fundamentalists admit that aspects of their beliefs, practices and institutions vary in time and place, even if they define these as secondary to an unchanging core. For example male circumcision among Christians who follow the Holy Bible was emphasized in the Old Testament, but this was not the case in the New Testament [31].

The social construction theory, which stipulates that social processes affect people's interpretation of what is happening around them, is illustrated by observations on the Nigerian situation regarding the difference in HIV prevalence between Muslims and Christians. This country is known for conflicts between Muslims and Christians. Within Nigeria the highest prevalence of HIV is found in Christian areas. All states with an HIV prevalence above $6 \%$ have predominantly Christian populations. The prevalence rate within predominantly Muslim states is between $2-4 \%$, which is approximately half of that of the predominantly Christian states. As a result of religious conflicts in Nigeria, Muslims and Christians give different explanations for the difference in HIV prevalence rates. The assumptions made in these explanations may not be true and may be the result of the conflict situation in which the communities reside, which may lead to stereotyping each other. For instance, some Nigerian Muslims argue that Christians are more lax in following the moral code set forth by their religion leading to higher HIV infection rates. Some Nigerian Christians on the other hand argue that the societal enforcement of the Islamic code is more oppressive. They conclude that Islam is more repressive and less forgiving than Christianity. The lower rates of HIV infection among Nigerian Muslims are therefore a result of the oppressive nature of Islam as a religion. For example, while Christians do not encourage sex outside marriage, social stigma is the harshest punishment a person would receive if their extra-marital sex is discovered. Individuals are accountable to God and any punishment for extramarital sex would come from God rather than from the community. Muslims on the other hand could be punished by stoning or flogging using the system of Islamic law (Shari'a) for proven offences of sex outside marriage. However, because of the difficulty in implementing Shari'a law related to sexual offences, some Muslims follow the rules of their religion but many others do not. This is why it may be found that there is no significant difference in sex outside marriage between Muslims and Christians.

The scholars on the Nigerian situation argue that instead of explaining away the difference in HIV prevalence rates with dubious assumptions that Muslims are sexually oppressed while Christians are not, there are two other factors that may cause a difference in these two communities namely alcohol drinking and male circumcision. Christianity does not advocate for excessive drinking of alcohol but it is not forbidden to drink. However, alcohol drinking is forbidden in Islam. Alcohol consumption makes it more likely for an individual to engage in high-risk sexual behaviors that may lead to HIV infections. Muslims worldwide are more likely to adhere to the guidelines discouraging alcohol use compared to Christians. Since Muslims do not get the inhibition of self-control caused by alcohol they 
are more likely to avoid risky sexual behaviors that may lead to HIV infections. Muslims are more likely to adhere to the guidelines regarding avoiding alcohol consumption than those related to extra-marital sex probably because of the circumstances of these actions. People engage in extramarital sex secretly but alcohol is often consumed in public and its effects are more easily manifested in public. Since alcohol is forbidden, a Muslim would not want to be associated with its consumption. Alcohol consumption is not encouraged among Christians but it is still socially acceptable and is not frowned upon as much as it is done among Muslims.

Male circumcision has been found by researchers to result in a $60 \%$ reduction in HIV infections. In many parts of the world male circumcision depends almost entirely on religion. Christians are generally not circumcised but circumcision among Muslims is either strongly recommended or mandatory depending on how Islamic teachings are interpreted. As a result of circumcision, Muslim men are less likely to get HIV infections compared to their Christian counterparts regardless of their sexual behaviors.

Some people in Nigeria have tried to turn the spread of HIV infection into a contest between Christianity and Islam. This is inter-religious competition rather than inter-religious cooperation. However, the difference between HIV prevalence rates between Christians and Muslims cannot be simply explained by claims that Christians are more promiscuous and Muslims more repressed. Many Christians adhere faithfully to a strict moral code provided by their religious teachings. There are also many Muslims who ignore the deterrent punishment of Shari'a law and engage in risky sexual behaviors. The most important causes of the differences in HIV prevalence between Muslims and Christians appear to be alcohol use and circumcision. However, the issue of HIV transmission and religion is more complex. It is not simply a black and white moral battle ground. It is likely that there are other possible explanations that may need to be explored [32].

The possible explanations for the difference in HIV prevalence between Muslims and Christians given by scholars on the Nigerian situation, could also apply to the Ugandan situation. However, the scholars on the Nigerian situation did not provide empirical data on the possible explanations they proposed. Our study provides empirical quantitative data in support of male circumcision and alcohol drinking being possible major factors that explain the difference in HIV prevalence between Muslims and Christians. In the spirit of inter-religious cooperation, Christian religious leaders may wish to strengthen their own faith teachings regarding these risk factors. For instance, as a result of the high burden of HIV/AIDS and the scientific information of what is likely to reduce new HIV infections, Christian religious leaders may wish to consider using teachings in their faith tradition similar to those in the Islamic faith tradition, in order to reduce the risk of HIV transmission among their communities. For example on circumcision one teaching from the Old Testament in the Holy Bible is as follows:

God said to Abraham, "You also must agree to keep the covenant with me, both you and your descendants in future generations. You and your descendants must all agree to circumcise every male among you. From now on, you must circumcise every baby boy when he is eight days old, including slaves born in your homes and slaves bought from foreigners. This will show that there is a covenant between you and me. Each one must be circumcised and this will be a physical sign to show that my covenant with you is ever lasting. Any male who has not been circumcised will no longer be considered one of my 
people, because he has not kept the covenant with me. (Holy Bible Genesis 17:1-14. Quoted from the Good News Bible published by The United Bible Societies).

Another teaching from the New Testament of the Holy Bible is as follows:

A week later, when the time came for the baby to be circumcised, he was named Jesus, the name which the angel had given him before he had been conceived. (Holy Bible, Luke 2:21. Quoted from the Good News Bible published by the United Bible Societies).

These teachings may be used by the Christian religious leaders to encourage circumcision within their communities using the faith-based approach to HIV/AIDS. The faith-based approach to HIV/AIDS proposed by IMAU and supported by other stakeholders such as the Inter-Religious Council of Uganda (IRCU), has the following five pillars: (1) believing in God; (2) acquiring scientific knowledge about HIV/AIDS; (3) making use of relevant faith teachings and practices; (4) forming partnerships with and making use of religious leaders and their administrative structures; and (5) making use of the concept of self-control (struggle of the soul against temptation) by each individual to combat HIV/AIDS [14]. Using this approach the religious value of circumcision may be upgraded by Christian religious leaders and their followers. This begins with the individual believing in God who gives guidance through the Holy Bible and the examples of Abraham and Jesus Christ. The individual then learns the scientific knowledge that circumcision reduces the risk of HIV infection. Then he uses relevant faith teachings that God recommends circumcision in the Holy Bible and that even Jesus Christ was circumcised. He works with his religious leaders to support him regarding upgrading the religious value of circumcision. He uses the concept of self-control to get circumcised and to circumcise his male children despite other alternative competing opinions.

Regarding drinking alcohol, one teaching from the Old Testament of the Holy Bible which may be used is as follows:

Show me someone who drinks too much, who has to try out some new drink and I will show you someone miserable and sorry for himself, always causing trouble and always complaining. His eyes are bloodshot and he has bruises that could have been avoided. Don't let wine tempt you, even though it sparkles in the cup and it goes down smoothly. The next morning you will feel as if you had been bitten by a poisonous snake. Weird sights will appear before your eyes, and you will not be able to think or speak clearly. You will feel as if you were out on the ocean, sea-sick, swinging high up in the rigging of a tossing ship. "I must have been hit", you will say; "I must have been beaten up, but I don't remember it. Why can't I wake up? I need another drink”. (Holy Bible: Proverbs 23:29-35. Quoted from the Good News Bible published by The United Bible Societies).

This teaching may be emphasized by Christian religious leaders in order to discourage alcohol drinking. This may be done by using the faith-based approach to HIV/AIDS prevention. Through this approach, the religious value of avoiding alcohol may be upgraded by the religious leaders and their followers and the concept of self-control strengthened for the purpose of encouraging abstaining from drinking alcohol despite alternative tempting views. There are several Christian religious 
denominations that have upgraded the religious value of avoiding alcohol consumption and forbidden drinking altogether. These include Jehovah's Witnesses, Seventh Day Adventists and Mormons [33].

It is important to note that both Muslim and Christian communities need to continue to use their faith teachings to increase other behaviors likely to reduce new HIV infections. These include abstinence from sex before marriage, being faithful in marriage, and avoiding narcotic drug use for recreation. It should be appreciated that some youth may understand the value of religious-based advice on safe sexual behaviors but they may find it difficult to follow it as observed by some researchers in Uganda [34]. It requires regular reminders to support the youth and other people having this difficulty. Both Muslim and Christian religious leaders need to consider sharing their experiences in addressing this difficulty since they appear to face the same problem according to the findings of our study.

It has been noted that Christianity and Islam are resolute in proposing high ideals for their followers. They require sexual abstinence outside marriage and fidelity within marriage. They should use this strength to contribute constructively to the reduction of HIV transmission and the care and support of those living with HIV/AIDS. They should avoid situations where their religions may lead to stagnation of their efforts to advance their religious ideals for promoting HIV prevention and control. For example, the condom debate has tended to polarize HIV/AIDS workers into those who favor and those who oppose condom use. This has sometimes resulted in drawing attention and energy away from the other positive positions and activities promoted by the religions. It is recommended that the condom debate should be put to rest and energy directed to the positive activities of the faith communities in addressing the HIV/AIDS epidemic. Another barrier that may obstruct faith-based efforts to address HIV/AIDS is moral condemnation and stigmatization. This is where HIV/AIDS is taken as God's punishment on an individual who has sinned by being sexually promiscuous or using narcotic drugs. This may stigmatize people living with HIV/AIDS labeling them as sinners who deserve HIV/AIDS as their punishment from God. It must be realized that people living with HIV/AIDS are crucial in reducing new HIV infections, regardless of how they got the infections. If they participate in preventing HIV transmission, the virus will not be transmitted. If they are stigmatized and left out, HIV transmission is more likely to continue. A key message that religious bodies need to disseminate vigorously and continuously is that HIV/AIDS is a sickness and not a sin and that we need people living with HIV/AIDS to actively participate in the faith-based approach to HIV/AIDS prevention, treatment and care essentially as a religious duty [35].

\section{Conclusions}

In conclusion, inter-religious cooperation between Muslims and Christians to address HIV prevention for the common good is achievable. It has the potential for increasing understanding of the similar faith teachings that the two faith communities share and how to use these teachings in their HIV prevention response for the good of their communities who are neighbors to each other. This is in line with what United States President Barack Obama said when addressing this issue in a speech he made in Cairo in 2009. He stated that "The interests we share as human beings are far more powerful than the forces that drive us apart" [1]. 
Both Muslims and Christians need to work together in cooperation rather than competition to ensure that the interests they share as human beings to prevent new HIV infections are made more powerful than the forces that drive them apart. This inter-religious cooperation is encouraged in their faith teachings. The following teachings from the Holy Qur'an illustrate this point.

To Him belong the keys of the heaven and the earth. He enlarges and restricts the sustenance to whom He will: for He knows full well all things. The same religion He has established for you as that which He enjoined on Noah - that which We have sent by inspiration to you - and that which we enjoined on Abraham, Moses, Jesus: namely that you should remain steadfast in religion and make no divisions therein: to those who worship other things than Allah, hard is the way to which you call them. Allah chooses to Himself those whom He pleases, and guides to Himself those who turn to Him. And they became divided only after knowledge reached them - through selfish envy between themselves. Had it not been for a Word that went forth before from your Lord tending to a term appointed, the matter would have been settled between them: but truly those who have inherited the Book after them are in suspicious disquieting doubt about it. (Holy Qur'an 42:13-14. Translated by Abdullah Yusuf Ali).

This teaching encourages inter-religious cooperation because the force that brings religions together which is God is more powerful than the force of selfish envy which drives them apart. However, once the overall purpose of religion is understood and implemented, which is to serve God by doing good to all, then the negative forces that divide the religions are more likely to be overcome. The following teaching from the Holy Qur'an illustrates this issue:

Serve Allah, and join not any partners with Him: and do good to parents, kinsfolk, orphans, those in need, neighbors who are near, neighbors who are strangers, the companion by your side, the way-farer you meet, and what your right hands possess: for Allah does not love the arrogant, the boastful. (Holy Qur'an 4:36 Translated by Abdullah Yusuf Ali).

Inter-religious cooperation for HIV prevention can be realized if all stakeholders make deliberate and concerted efforts towards this goal for the good of their communities. From our study, Muslims and Christians working and learning together as good neighbors, can generate evidence-based data that can assist them to improve their HIV prevention interventions. By sharing these data, each community is likely to benefit from their cooperation by strengthening within each religious tradition, those behaviors and practices that appear helpful in reducing new HIV infections. In this way, both communities can do good to each other by promoting good behaviors that reduce HIV transmission using similar faith teachings in each religious tradition. This is the recommended way that neighbors should treat each other according to faith teachings of both religions. These encourage treating the neighbor like one would like to be treated. Our study has highlighted some of the benefits that may arise if this recommendation is followed. Without inter-religious cooperation it would not be easy to obtain the kinds of data we have presented here. With inter-religious cooperation, opportunities for both communities to do good to their neighbors and support each other in their HIV prevention response are more likely to be enhanced. 
These data from our study, obtained from a large sample of Muslim and Christian youth 15-24 years, will form a baseline which will be used to monitor and evaluate trends in HIV prevalence and HIV-risk behaviors periodically every 2-3 years in these groups, depending on availability of resources. The HIV prevalence was lower among Muslim youth. The significant differences between Muslim and Christian youth related to HIV-risk behaviors concern male circumcision and the age at which it is done; age of initiation of sex; ever-use of alcohol; ever been drunk; drinking now and ever taken alcohol before sex. These are the behaviors that need to be emphasized in future interventions involving inter-religious cooperation within these communities. Assuming IMAU and other stakeholders are able to mobilize resources for intensive interventions to support these religious communities to address the targeted HIV-risk behaviors using the faith-based approach to HIV/AIDS, then changes are expected to be observed in future. It would be very impressive if the differences in HIV prevalence and HIV-risk behaviors could be erased among the Muslim and Christian youth in these communities following intensive interventions implemented with inter-religious cooperation. However, it has been noted that while research on religion and health is expanding, it is not well funded [36]. This is an issue that needs to be addressed by all stakeholders interested in inter-religious cooperation and the faith-based approach to HIV/AIDS prevention, treatment and care. For inter-religious cooperation for HIV prevention to flourish, it must be supported by appropriate funding mechanisms. As far as combating HIV/AIDS is concerned, religion can be likened to a "sleeping giant." It is likely to have a great positive impact on HIV/AIDS prevention, treatment and care if it is awakened and supported through inter-religious cooperation.

\section{Acknowledgments}

We are grateful to the Government of Uganda, United State Agency for International Development (USAID), Centers for Disease Control and Prevention (CDC), President's Emergency Plan for AIDS Relief (PEPFAR), UNAIDS, UNICEF, WHO and UNDP for providing funding to support HIV/AIDS projects of the Islamic Medical Association of Uganda (IMAU) over the years. We are also grateful to the communities and their leaders in various districts of Uganda for participating in IMAU projects and especially those in Wakiso district for participating in this study. We would also like to thank all the staff of Saidina Abubakar Islamic Hospital who participated in data collection, entry and analysis for the study and all members of IMAU for their inputs to the association. The support given to IMAU by Makerere University School of Public Health - CDC/HIV/AIDS Fellowship Program, InterReligious Council of Uganda (IRCU), Protecting Families Against AIDS (PREFA), Mulago-Mbarara Teaching Hospitals' Joint AIDS Program (MJAP), Uganda Ministry of Health, Uganda AIDS Commission and Federation of Islamic Medical Associations (FIMA), is very much appreciated.

\section{References}

1. President's Advisory Council on Faith-Based and Neighborhood Partnerships. Task force on Inter-Religious Cooperation. In A new Era of Partnerships: Report of Recommendations to the President; The White House: Washington, DC, USA, 2010; pp. 69-94. Available online: http://www.whitehouse.gov/partnerships (Accessed on 8 July 2011). 
2. Frumence, G.; Killewo, J.; Kwesigabo, G.; Nystrom, L.; Eriksson, M.; Emmelin, E. Social capital and the decline in HIV transmission - A case study in three villages in the Kagera region of Tanzania. SAHARA J. 2010, 7, 9-20.

3. Iannaccone, L.; Klick, J. Spiritual capital: An introduction and literature review. 2003. Available online: www.spiritualcapitalresearchprogram.com (Accessed on 8 October 2011).

4. Finke, R. Spiritual capital: Definitions, Applications, and New frontiers, 2003. Available online: http:www.spiritualcapitalresearchprogram.com under articles (Accessed on 8 October 2011).

5. Smith, J. South Africa interfaith solidarity: A model for social transformation. 2007. Available online: http://www.inter-disciplinary.net/ati/diversity/multiculturalism/mcb1/Smith\%20paper.pdf (Accessed on 8 October 2011).

6. Said, A.A. Bridges, not Barriers: The American Dream and the Global Community; Fetzer Institute: Kalamazoo, MI, USA, 2006.

7. Kagimu, M.; Marum, E.; Serwadda, D. Planning and evaluating strategies for AIDS health education interventions in the Muslim community in Uganda. AIDS Educ. Prev. 1995, 7, 10-21.

8. Kagimu, M.; Marum, E.; Wabwire-Mangen, F.; Nakyanjo, N.; Walakira, Y.; Hogle, J. Evaluation of the effectiveness of AIDS health education interventions in the Muslim community in Uganda. AIDS Educ. Prev. 1998, 10, 215-228.

9. Kirby, D. Success in Uganda: An Overview of Uganda's Campaign to Change Sexual Behaviors and Decrease HIV Prevalence, 1986-1995; ETR Associates: Scotts Valley, CA, USA, 2008.

10. Summer, C. Catholic action and Uganda radicalism: Political activism in Buganda, 1930-1950. J. Relig. Af. 2009, 39, 60-90.

11. UNAIDS. AIDS Education through Imams: A Spiritually Motivated Community Effort in Uganda; UNAIDS: Geneva, Switzerland, 1998; UNAIDS Best Practice Collection.

12. Adeshina, S.A. Achieving a better understanding of our differences-inter-religious cooperation in Nigeria. In Religion and Inter-religious Dialogue: The Role of Religion in German and African Societies; Schwartz, A., Bergmann, J., Popper, L., Eds.; bpb: Bonn, Germany, 2011.

13. Kagimu, M. Faith-based community mobilization and education for antiretroviral therapy in Uganda. Sex. Health Exchange 2003, 3, 12-14.

14. Islamic Medical Association of Uganda. Faith-based Approach to HIV/AIDS: Enhancing the Community Response. Training Guidelines for Religious Leaders, Community Educators and the Communities; IMAU: Kampala, Uganda, 2007.

15. Badri, M. The AIDS crisis: A Natural Product of Modernity's Sexual Revolution, 3rd ed.; Medeena Books: Kuala Lumpur, Malaysia, 2000.

16. Uganda AIDS Commission. HIV Prevention Response and Modes of Transmission Analysis; Uganda National AIDS Commission: Kampala, Uganda, 2009.

17. Malamba, S.; Wagner, H.; Mande, G.; Okongo, N.; Nunn, A.; Kengeya-Kayondo, J.; Mulder, D. Risk factors for HIV-1 infection in adults in a rural Uganda community: A case-control study. AIDS 1994, 8, 253-257.

18. Uganda Population and Housing Census. Uganda Bureau of Statistics, Kampala, Uganda, 2002.

19. Ministry of Health (MOH) (Uganda) and ORC Macro. Uganda HIV/AIDS Sero-behavioral Survey 2004-2005; Ministry of Health and ORC Macro: Calverton, MD, USA, 2006. 
20. Hladik, W.; Musinguzi, J.; Kirungi, W.; Opio, A.; Stover, J.; Kaharuza, F.; Bunnell, R.; Kafuko, J.; Mermin, J. The estimated burden of HIV/AIDS in Uganda 2005-2010. AIDS 2008, 22, 503-510.

21. Otolok-Tanga, E.; Atuyambe, L.; Murphy, C.; Ringheim, K.; Woldehanna, S. Examining the actions of faith-based organizations and their influence on HIV/AIDS related stigma: A case study of Uganda. Afr. Health Sci. 2007, 7, 55-60.

22. Kibuuka, H. Religiosity and attitudes on intimancy. Implications for the HIV/AIDS pandemic in central Uganda. Master's thesis, Duquesne University, Pittsburgh, PA, USA, 2005.

23. Bertozzi, S.M.; Laga, M.; Bautista-Arredondo, S.; Coutinho, A. Making HIV prevention programs work. Lancet 2008, 372, 831-844.

24. Uganda Ministry of Health. HIV Counseling and Testing. A National Counselor Training Manual; MOH: Kampala, Uganda, 2005.

25. Nunn, A.; Kengeya-Kayondo, J.; Malamba, S.; Seeley, J.; Mulder, D. Risk factors for HIV -1 infections in adults in a rural Ugandan community: A population study. AIDS 1994, 8, 81-86.

26. Carpenter, L.; Kamali, A.; Ruberantwari, A.; Malamba, S.; Whitworth, J. Rates of HIV-1 transmission within marriage in rural Uganda in relation to the HIV sero-status of the partners AIDS 1999, 13, 1083-1089.

27. Gray, H.; Kiwanuka, N.; Quinn, T.C.; Sewankambo, N.K.; Serwadda, D.; Mangen, F.W.; Lutalo, T.; Nalugoda, F.; Kelly, R.; Meehan, M.; Chen, M.Z.; Li, C.; Wawer, M.J. Male circumcision and HIV acquisition and transmission: Cohort studies in Rakai Uganda. AIDS 2000, 14, 2371-2381.

28. Gray, P. HIV and Islam: Is HIV prevalence lower among Muslims? Soc. Sci. Med. 2004, 58, 1751-1756.

29. Uganda AIDS Commission. Moving Toward Universal Access: National HIV \& AIDS Strategic plan 2007/8 - 2011/12; Uganda AIDS Commission: Kampala, Uganda, 2007

30. Gilbert, S. The Influence of Islam on AIDS Prevention among Senegalese University Students. AIDS Educ. Prev. 2008, 20, 399-407.

31. Engler, S. Two problems with constructionism in the study of religion. Revista de Estudos da Religiao 2005, 4, 28-34.

32. The Institute of Global Engagement. Religion and HIV and AIDS in Nigeria. 2006. Available online: www.globalengage.org/media/article:aspx?id=2034 (Accessed on 5 November 2011).

33. Koening, H.G. Spirituality in Patient Care, 2nd ed.; Templeton Foundation Press: Philadelphia, PA, USA, 2007.

34. Rasjo, E.; Darj, E. "Safe sex advice is good - but so difficult to follow": Views and experiences of the youth in a health centre in Kampala. Afr. Health Sci. 2002, 2, 107-113.

35. Kelly, M. The role of religion in the HIV/AIDS epidemic (with special reference to Christianity and Islam), 2003. Available online: http://www.missioncouncil.se/download/18.51ddd3b10fa0c6 4b24800024901/religion_hiv_aids_michael_kelly.pdf (Accessed on 10 October 2011).

36. Koenig, H.G.; Bussing, A. The Duke University Religion Index (DUREL): A five-item Measure for use in Epidemiological studies. Religions 2010, 1, 78-85.

(C) 2011 by the authors; licensee MDPI, Basel, Switzerland. This article is an open access article distributed under the terms and conditions of the Creative Commons Attribution license (http://creativecommons.org/licenses/by/3.0/). 